\title{
Palaeoenvironmental evolution from the early Holocene to the present of the Almenara marsh (western Mediterranean)
}

\author{
Ana M. Blázquez-Morilla, Ana Rodríguez-Pérez, Daniel Sanjuán-Lamata
}

Environmental and Marine Sciences Research Institute, Catholic University of Valencia, C/ Guillem de Castro 94, 46003 Valencia, Spain.

(AMB-M) (Corresponding author) E-mail: Ana.blazquez@ucv.es. ORCID iD: https://orcid.org/0000-0002-7174-8601

(AR-P) E-mail: ana.rodriguez@ucv.es. ORCID iD: https://orcid.org/0000-0002-2861-558X

(DS-L) E-mail: danisl@mail.ucv.es. ORCID iD: https://orcid.org/0000-0002-8176-324X

\begin{abstract}
Summary: The main aim of this study is to characterize the different stages in the palaeoenvironmental evolution of the Almenara marsh, Spain, from the early Holocene to the present day. This marsh is one of the most important in Castellón province. Five cores extracted from the marsh underwent sedimentological analysis, micropalaeontological study (foraminifera, ostracods and gastropods) and ${ }^{14} \mathrm{C}$ dating. The results show that before the maximum transgression of the Mediterranean during the Marine Isotope Stage 1 (5500 cal yr. BP dating in the Almenara marsh), the area was occupied by a brackish marsh (prior to the $8.2 \mathrm{ka}$ event). During the middle Holocene, the regional sea level rise and later stability caused an oligohaline/freshwater marsh with fluctuating water levels to form. This marsh occupied the entire area of today's Almenara marsh at least between 7570 and $2780 \mathrm{cal}$ yr BP. The results may indicate a phase of greater contribution of groundwater inputs (and rainfall/riverine discharge) during the middle Holocene as a response to a climatic phase characterized by higher humidity. Today, the marsh is filled with sediments from natural and anthropic processes related to the agricultural activity carried out throughout the area (except for the central part, which has been reclaimed as wetland). The water of the present-day marsh (like that prior to 8.2 ka event) is brackish, as is indicated by the benthic foraminiferal assemblage; this contrasts with the earlier oligohaline/freshwater marsh determined in the survey cores during the middle Holocene until the time of the Iberian culture.
\end{abstract}

Keywords: marsh; fossil foraminifera; present foraminifera; sediment; Holocene; evolution.

Evolucion paleoambiental desde el Holoceno temprano hasta la actualidad del marjal de Almenara (Mediterráneo occidental)

Resumen: El principal objetivo de este trabajo es la caracterización de los diferentes estadios en la evolución paleoambiental del marjal de Almenara (España) desde el Holoceno temprano hasta la actualidad. Este espacio húmedo es uno de los más importantes de la provincia de Castellón. Se han estudiado cinco testigos sedimentarios que han sido analizados desde el punto de vista sedimentológico, micropaleontológico (especialmente foraminíferos) y cronológico $\left({ }^{14} \mathrm{C}\right)$. Los resultados muestran que antes del máximo de la transgresión en el Mediterráneo del Estadio Isotópico 1 (5500 cal yr. BP datado en el marjal de Almenara), el área estaba ocupada por una marjal salobre (antes del evento frío y seco del 8.2 ka). Tras la desecación de este ambiente (en el episodio $8.2 \mathrm{ka}$ ), durante el Holoceno medio, el incremento del nivel del mar y su posterior estabilidad determinó la instalación de un marjal oligohalino y/o dulceacuícola, en el cual se constatan fluctuaciones del nivel del agua. Este ambiente ocupó el área de estudio al menos entre 7570 and $2780 \mathrm{cal}$ yr BP. Los resultados indican una contribución más importante del acuífero (de la lluvia y de la escorrentía superficial) durante el Holoceno tardío, que contrarrestó el ascenso eustático, como respuesta a una fase climática mucho más húmeda que la actual. Hoy, el marjal está colmatado por sedimentos procedentes de procesos naturales y antropogénicos, vinculados a las actividades agrícolas que se desarrollan desde hace siglos, excepto en la parte central que ha sido recuperada como zona húmeda. El marjal actual es salobre (igual que el registrado antes del episodio $8.2 \mathrm{ka}$ ), como corroboran las asociaciones de foraminíferos bentónicos, lo cual contrasta con las asociaciones fósiles que revelan un paleoambiente oligohalino y/o dulceacuícola durante el Holoceno medio hasta la época de la cultura ibérica.

Palabras clave: marjal; foraminíferos fósiles; foraminíferos actuales; sedimentos; holoceno; evolución.

Citation/Como citar este artículo: Blázquez-Morilla A.M., Rodríguez-Pérez A., Sanjuán-Lamata D. 2018. Palaeoenvironmental evolution from the early Holocene to the present of the Almenara marsh (western Mediterranean). Sci. Mar. 82(4): 257-268. https://doi.org/10.3989/scimar.04853.07A

Editor: E. Calvo

Received: September 6, 2018. Accepted: November 30, 2018. Published: December 12, 2018.

Copyright: ( 2018 CSIC. This is an open-access article distributed under the terms of the Creative Commons Attribution 4.0 International (CC BY 4.0) License. 


\section{INTRODUCTION}

Marshes and lagoons are highly characteristic morphologies of the western Mediterranean coastline, especially along the eastern coast of Spain. They record complete sedimentary sequences during the recent interglaciar period. For this reason, these coastal systems have been extensively studied. Sedimentological and geomorphological studies performed in the western Mediterranean (Dupré et al. 1988, Fumanal et al. 1993, Carmona et al. 2016) have allowed a model of palaeoenvironmental evolution from the Pleistocene to the present day to be developed. According to the regional model proposed by these studies, the development of the present marshes occurred during the maximum transgression of the Mediterranean Sea in the mid-Holocene, likely around 6000-5000 yr BP. These studies show that there were three main causes of the palaeoenvironmental changes in these sequences: eustatic variations, climate changes and tectonic movements. The regressive position of the sea level towards the end of the Pleistocene led to the displacement of the alluvial material and the relocation of the river mouth towards areas currently occupied by the sea. In this time, between $18000 \mathrm{BP}$ and the early Holocene, erosive processes predominated (Blázquez and Usera 2010). After the $8.2 \mathrm{ka}$ event, in line with a process of global warming, the sea level continued to rise to the eustatic maximum (6000-5000 yr BP), about 2 m.a.s.l., as suggested by Pirazzoli (2005), followed by a gradual fall to the present-day level. When the sea level stabilized, the sediment deposits from rivers formed gravel beach barriers and spits around river mouths (Carmona and Ruiz 2011), causing the retention of fine sediments (clay and silt) and therefore the sedimentation processes in the river mouths, estuaries and deltas (Anthony et al. 2014). In addition, regional changes in climate (i.e. greater aridity and intense rainfall) have affected the rate of sediment reaching the coast, which has risen considerably from $4000 \mathrm{BP}$ to the present (Dupré et al. 1988, Carrión et al 2010). The increase or decrease of precipitation affects the flow of the rivers, their transport capacity and competence, and the aquifer reservoir. Finally, though the effect of tectonics was local, it played a decisive part in the relative position of the sea level and therefore in the inland advance of the sea.

Today, a fourth factor is the increasing impact of human activity in recent times. The wetlands in this region were especially affected by human activity during the $19^{\text {th }}$ and $20^{\text {th }}$ centuries, when marshes and lagoons were drained in order to gain more agricultural land (Rosselló 1993). Today, most of these wetlands have been designated as protected areas in an attempt to recover these ecosystems and their rich biodiversity.

These four factors all influenced the geomorphological and palaeoenvironmental changes in western Mediterranean marshes during the Holocene. In this context, the main aim of this paper is to trace the palaeoenvironmental evolution of the Almenara marshland from the early Holocene to the present day, and to assess the role played by climate, sea level oscillations and human activity, especially in more modern times.
To do so, a sediment core (S-8) was obtained in the northern area of the Almenara marsh and correlated with four cores from its southern part (S-1, S-2, S-3, S-4; Blázquez et al. 2017); core S-8 records an older facies that is not identified in the southern cores. Therefore, this paper proposes a more complete sequence of the evolution of the study area during the Holocene. The foraminiferal assemblage studied in the palaeoenvironments recorded is compared with the present-day assemblage through the sampling of the Estany de Almenara (Fig. 1).

\section{STUDY AREA}

The study area is the Almenara marsh, located in the southern part of the province of Castellón (Fig. 1A), on the Mediterranean coast of Spain. This wetland has recently been included in the RAMSAR Convention (the Convention on Wetlands) due to its important biodiversity. Today, the marsh covers 1500 ha. It has been silted due to natural causes and anthropogenic activity, and $70 \%$ of the area of the marsh is used for agricultural purposes. The Estany de Almenara, a wetland, currently occupies $20 \%$ of this area (Fig. 1B). It is located in the centre of the marsh and has an average depth of about $7 \mathrm{~m}$. This small wetland is the result of the recent attempts to recover the marsh, funded by regional and national authorities, which have done a great deal to reinstate the area's biodiversity. The inlet is isolated from the marine environment by a system of sluice gates that prevent the direct entry of the sea and thus protect the crops from the seawater.

From the geological and geomorphological point of view, the study area is limited by the reliefs of the Iberian mountain range (NW-SE) that form the Sierra de Espadán and the Sierra Calderona. It is located in a depression that originated during the late Oligocene/ Miocene due to the intersection of orthogonal faults of Iberian orientation with others running NE-SW, which produced a subsiding tectonic depression (Fontboté et al. 1990). This depression was filled with alluvial deposits and alluvial piedmonts during the Pliocene and Quaternary (Pérez Cueva 1979), which are connected to a sandbar-marsh system on the coast (Fig. 1C).

The wetlands are limited by two rivers, the Palancia to the south and the Belcaire to the north; the ancient alluvial fans of these rivers were the points of support of the barrier. The aquifer of Les Valls directly feeds the Estany de Almenara through the lateral aquifer of the Salto del Caballo (Fullana Montoro 2001). The systems of alluvial fans and alluvial piedmont slope connect the hillsides and plains that constitute the inner boundary of the marsh (Fig. 1C), where previous studies have defined several morphogenetic phases, starting in the lower-middle Pleistocene (Mediato 2016).

\section{MATERIALS AND METHODS}

For this study, core S-8 was investigated for sedimentological, palaeontological and chronological parameters. This core was obtained in the north of the current marsh area (Fig. 1C), $2.2 \mathrm{~km}$ from the coast, 


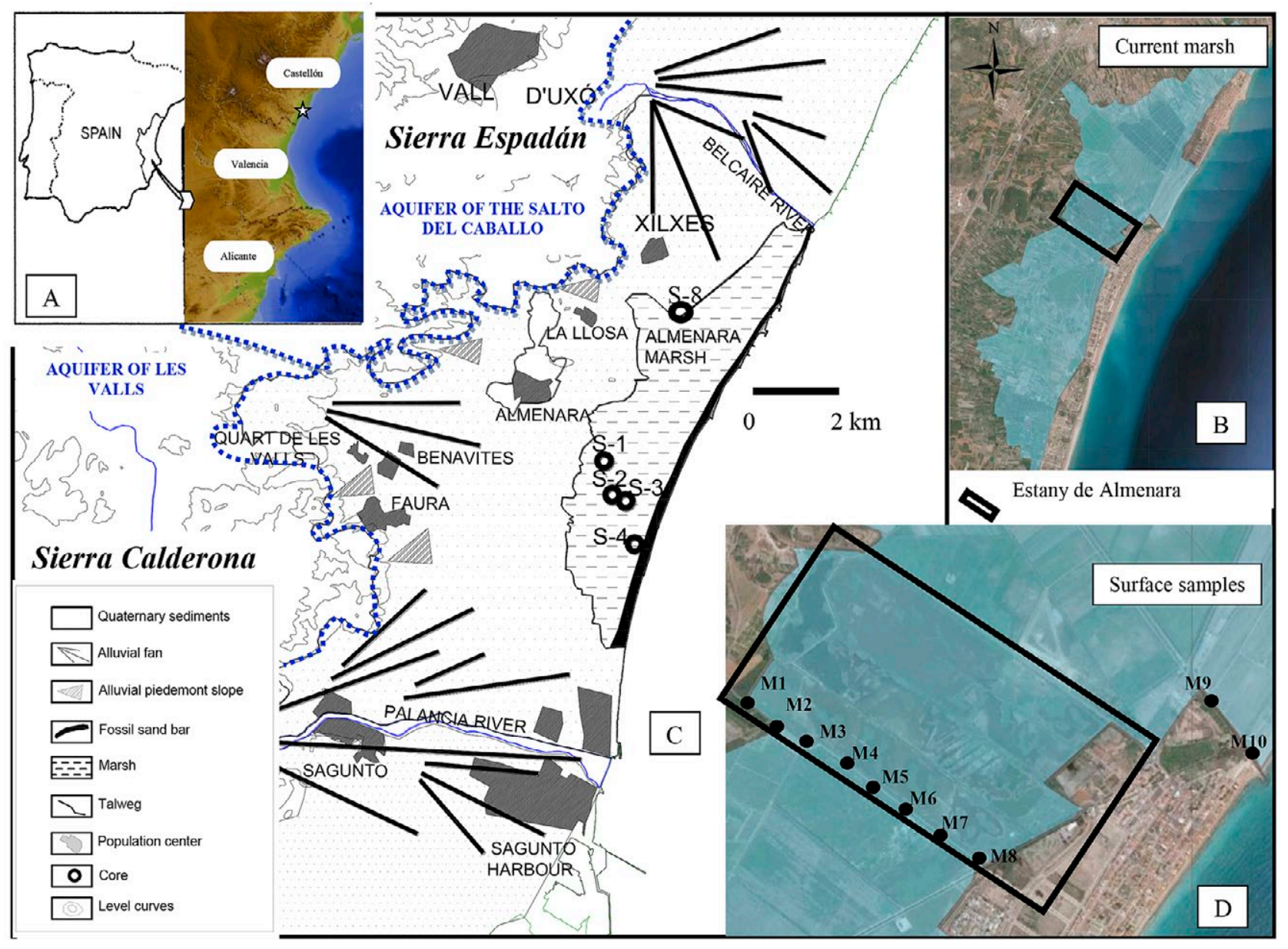

Fig. 1. - A, location of the study area. B, geomorphological map and situation of the mechanical cores and surface sediment samples. C, wetland reclaimed. $\mathrm{D}$, location of the surface samples.

UTM 30S 741280, 4405980 (WGS84), at $1.6 \mathrm{~m}$ altitude above mean sea level. It reached a depth of 10 $\mathrm{m}$ and was located in the area of contact between the alluvial fans that descend from the northern relief. The core was systematically sampled every $10 \mathrm{~cm}$. The sedimentological investigation focused on granulometrical analysis (differentiating between the proportion of sand and silt-clays) and the organic matter content (by the calcination method; loss of ignition) and calcium carbonate (with the Bernard calcimeter method; gas-volumetric determination). For the micropalaeontological investigation (i.e. the identification of foraminifera, charophytes, gastropods and ostracods), the samples were dried, weighed, dispersed in some cases (carbonated samples) with the help of sodium hydroxide and washed through a $0.063-\mathrm{mm}$ mesh. They were then floated in a dense liquid (trichloroethylene) to facilitate the recovery of the shells. Microfossil tests were studied using a stereomicroscope. In the samples with enough shells, at least 300 benthic foraminiferal tests were identified. The foraminiferal content was used to assess the diversity (Shannon and Wiener 1949), evenness, Margalef richness (Magurran 2001) and Fisher's alpha (Fisher et al. 1943) in order to establish the composition and proportional abundance of the species. Diversity indices were calculated only for samples with more than 50 tests. All calculations were performed with the PAST software package (Hammer et al. 2006). For the chronological study, one bulk organic sediment sample was ${ }^{14} \mathrm{C}$ dated using accelerator mass spectrometry (Beta Analytic, Florida, US). This sample was selected for dating because of the high organic matter content. Seven chronostratigraphic units (VII-I) were defined for the S-8 core, and were correlated with four cores: S-1 (UTM 30S 740079, 4402739, WGS84), S-2 (UTM 30S 740122, 4402080, WGS84), S-3 (UTM 30S 740182, 4402068, WGS84) and S-4 (UTM 30S 740710, 4401250, WGS84), which were previously studied using the same methodology (Blázquez et al. 2017, see Fig. 1C for locations). The authors of the study include chronologies for the upper part of the sequence which were provided by radiometric dating and are displayed in Table 1.

The present-day samples were collected in February 2013 in the marshland. The main objective was to characterize the present-day marsh from a micropalaeontological point of view. The data obtained were used as reference points for the palaeoenvironmental interpretation of the core samples. Furthermore, an oligohaline marsh environment (0.5-5 ppt) recorded in recent millennia (Blázquez et al. 2017) contrasted with the synchronous brackish marsh environments (5-30 ppt) recorded in nearby areas. These findings indicated the need to sample the present-day environment in order to 
Table 1. - Radiometric datings. ${ }^{14} \mathrm{C}$ (Beta Analytic, Florida, US) and amino acid racemization (AAR) (Laboratory of Biomolecular Stratigraphy, Madrid, Spain). Modified from Blázquez et al. (2017).

\begin{tabular}{|c|c|c|c|c|c|c|c|c|}
\hline Core & Sample & $\begin{array}{c}\text { Depth } \\
(\mathrm{m})\end{array}$ & Laboratory & $\begin{array}{c}\text { Conventional } \\
\text { Radiocarbon Age BP }\end{array}$ & $\begin{array}{c}\text { Measured } \\
\text { Radiocarbon Age }\end{array}$ & 2 Sigma Range & $\begin{array}{l}\text { AAR. } \\
\text { D/L Asp }\end{array}$ & Age \\
\hline S1 & 5 & 1.1 & LEB-12511-12513 & & & & $0.155 \pm 0.009$ & $3100 \pm 780 \mathrm{yr}$ \\
\hline S1 & 10 & 1.6 & LEB-12522-12523 & & & & $0.192 \pm 0.004$ & $7400 \pm 400 \mathrm{yr}$ \\
\hline S1 & 11 & 1.65 & Beta - 288411 & $6470 \pm 50{ }^{14} \mathrm{C}$ yr BP & $6500 \pm 50{ }^{14} \mathrm{C}$ yr & $\begin{array}{c}7460 \text { to } 7280 \mathrm{cal} \text { yr BP }(95.4 \%) \\
\text { Database INTCAL04 }\end{array}$ & & \\
\hline S3 & 7 & 0.95 & Beta - 288410 & $4280 \pm 40{ }^{14} \mathrm{C}$ yr BP & $4310 \pm 40{ }^{14} \mathrm{C}$ yr & $\begin{array}{c}4880 \text { to } 4820 \text { cal yr BP }(95.4 \%) \\
\text { Database INTCAL04 }\end{array}$ & & \\
\hline S3 & 14 & 1.5 & LEB-12533-12534 & & & & $0.179 \pm 0.002$ & $5600 \pm 250 \mathrm{yr}$ \\
\hline S3 & 16 & 1.7 & LEB-12535-12536 & & & & $0.180 \pm 0.003$ & $5700 \pm 200 \mathrm{yr}$ \\
\hline S3 & 18 & 1.9 & LEB-12539-12540 & & & & $0.181 \pm 0.002$ & $5800 \pm 200 \mathrm{yr}$ \\
\hline S3 & 29 & 2.8 & Beta - 288412 & $6610 \pm 40{ }^{14} \mathrm{C}$ yr BP & $6630 \pm 40{ }^{14} \mathrm{C}$ yr & $\begin{array}{c}7570 \text { to } 7430 \text { cal yr BP }(95.4 \%) \\
\text { Database INTCAL04 }\end{array}$ & & \\
\hline S8 & 7 & 0.77 & Beta - 386337 & $2640 \pm 30{ }^{14} \mathrm{C}$ yr BP & $2670 \pm 30{ }^{14} \mathrm{C}$ yr & $\begin{array}{c}2780 \text { to } 2740 \text { cal yr BP } \\
\text { Database INTCAL13 }\end{array}$ & & \\
\hline
\end{tabular}

rule out local factors that might reduce the salinity of the water. Two coring transects were selected, the first of them perpendicular to the coastline and consisting of eight sampling points and the second consisting of two sampling points located inside the inlet, an area that connects the sea with the marsh (Fig. 1D). At these points, bottom samples were taken by direct underwater extraction (by a driver) at a depth of one metre and with a penetration into the sediment of one centimetre. The samples were stored in plastic bottles with $10 \%$ formaldehyde to preserve the organic part of the living foraminifera. Two days later, in the laboratory, these samples were washed and sieved and subsequently stained with rose bengal (Walton 1952) diluted 1\% for one hour. From these samples, 300 foraminiferal tests were picked and identified at species level. We followed the taxonomic classification of Loeblich and Tappan (1987) and Hayward et al. (2017) for generic attributions. During these last steps, stained and unstained shells were analysed separately; living specimens were defined when tests were completely stained with the exception of the last chamber. Several ecological indices were calculated: the Shannon-Wiener H' index (Shannon-Wiener 1949) and Margalef richness (Magurran 2001).

\section{RESULTS}

\section{Benthic foraminifera in the present-day marsh}

The Estany de Almenara (Fig. 1D) was sampled in order to characterize the benthic foraminiferal assemblage in the present-day environment. Preliminary results of this study were presented by Sanjuán and Blázquez (2017). Samples M1-M8 were located in the interior of the marsh, following the direction of the line shown in Figure 1D, while M9-M10 were collected in the inlet that connects the marsh with the open sea. The marsh samples (M1-M8) were rich in silts and clays $(80 \%)$ and organic matter, and the samples from the inlet (M9 and M10) had a fine sand content of up to $40 \%$ and less than $60 \%$ of silty clay.

Surface samples (Table 2, Fig. 2) contained a total of 34 benthic foraminiferal species ( $c a .2900$ specimens), of which 137 were recognized alive by the time of sampling. The biocenosis thus constitutes $4.7 \%$ of the total of individuals studied, a far higher rate than those recorded in similar locations in the Mediterranean (Guillem 2007). Jennings and Nelson (1992), in coastal marshes of Oregon, recorded a variability of $3 \%$ to $69 \%$ in the proportion between live and dead foraminifera. In all, 2584 (89\%) of the studied shells were of the Rotaliida order (hyaline shell), representing 23 species. The most frequent (Table 2) were Ammonia tepida (Cushman, 1926), Paraphysalidia paralica (Guillem and Usera, 2012), Trichohyalus aguayoi (Bermudez, 1935) and Haynesina germanica (Ehrenberg, 1840), followed by other typical marsh species and species of the Miliolida (porcellaneous shell) and Lituolida orders (microgranular shell): Trochammina inflata (Montagu, 1808), Jadammina macrescens (Brady, 1870), Miliolinella eburnea (D'Orbigny, 1839) and Pseudothurammina limnetis (Scott and Medioli, 1980).

Ammonia tepida is found throughout the marsh. It is the main species from M1 (67\%) to M8 (31\%), where it coexists with Trichohyalus aguayoi (41\%). In M8 and

Table 2. - Number of individuals and species of benthic foraminifera $>1 \%$. Stained foraminiferal tests are indicated between brackets.

\begin{tabular}{|c|c|c|c|c|c|c|c|c|c|c|c|c|c|}
\hline Species & Order & M1 & M2 & M3 & M4 & M5 & M6 & M7 & M8 & M9 & M10 & Total & $\%$ \\
\hline Ammonia tepida & Rotaliida & $204(7)$ & 6 & $336(10)$ & $268(3)$ & $234(4)$ & $256(9)$ & $16(2)$ & $94(7)$ & $85(12)$ & $23(3)$ & 1522 & 53.6 \\
\hline Bolivina pseudoplicata & Rotaliida & & & & & 1 & & & 7 & $7(3)$ & 21 & 36 & 1.2 \\
\hline Haynesina germanica & Rotaliida & & & & 9 & & 16 & 1 & $4(3)$ & $23(3)$ & $70(12)$ & 123 & 4.3 \\
\hline Jadammina macrescens & Lituolida & 7 & & & & & 8 & 7 & & 7 & 1 & 30 & 1.0 \\
\hline Miliolinella eburnea & Miliolida & 5 & & & 1 & & & 1 & 17 & 14 & 35 & 73 & 2.5 \\
\hline Paraphysalidia paralica & Rotaliida & $55(6)$ & $286(9)$ & $25(1)$ & 6 & $38(2)$ & $31(6)$ & 10 & $16(2)$ & $37(1)$ & 10 & 514 & 18.1 \\
\hline Pseudothurammina limnetis & Lituolida & & & 9 & & & & & & 38 & 2 & 49 & 1.7 \\
\hline Rosalina mediterranensis & Rotaliida & 4 & & & 11 & & & & & $7(1)$ & $37(7)$ & 59 & 2.0 \\
\hline Trichohyalus aguayoi & Rotaliida & 31 & 3 & 11 & 9 & 22 & 5 & 8 & $124(4)$ & $8(3)$ & & 221 & 7.7 \\
\hline Trochammina inflata & Lituolida & & & & 2 & 7 & 2 & 6 & 10 & & & 27 & 1.0 \\
\hline $\mathrm{N}^{\mathrm{o}}$ species per sample & & 9 & 4 & 4 & 10 & 5 & 7 & 8 & 11 & 28 & 21 & 34 & 100 \\
\hline $\mathrm{N}^{\circ}$ of individuals per sample & & 314 & 301 & 381 & 309 & 302 & 323 & 50 & 297 & 310 & 251 & 2838 & 100 \\
\hline
\end{tabular}




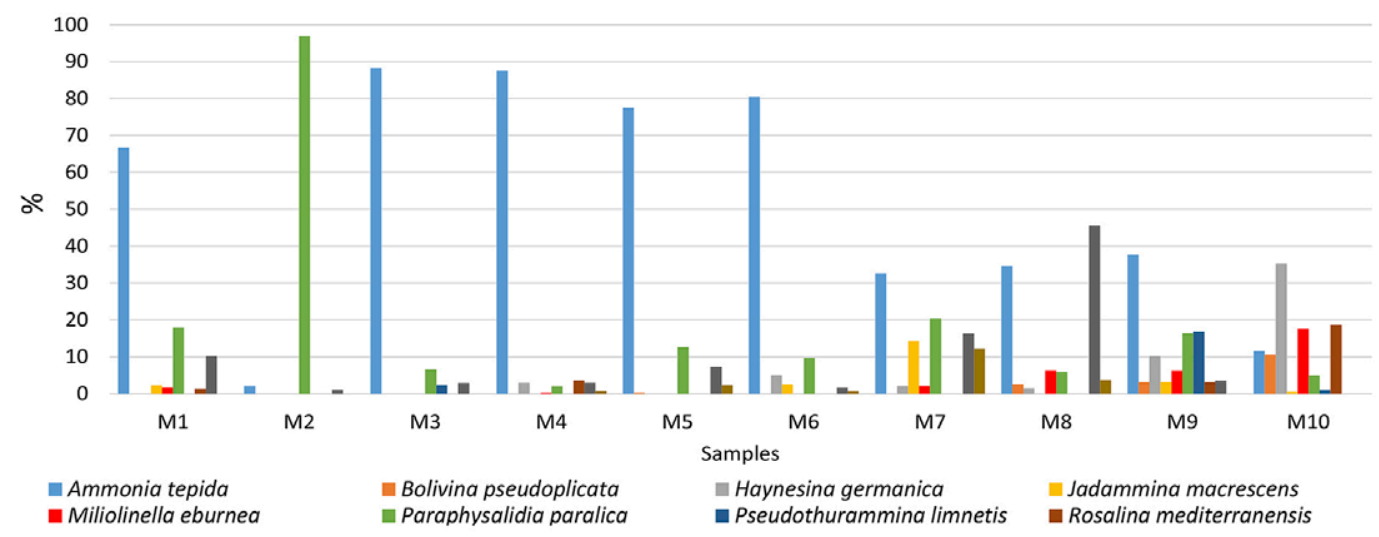

Fig. 2. - Benthic foraminiferal relative abundances from surface samples.
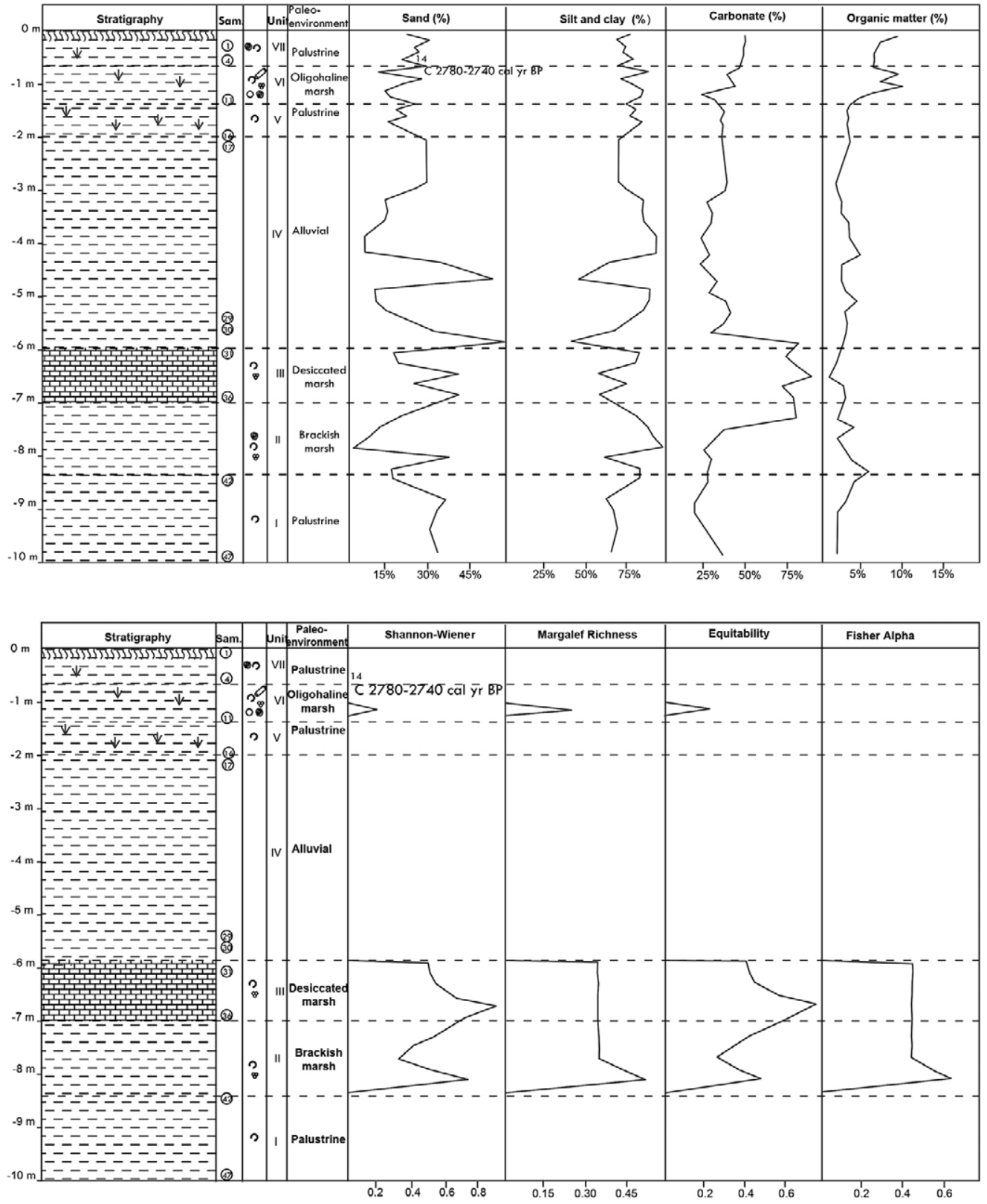

B

O Charophites

O Ostracods

\& Foraminifera

- Pebble flat

Rhizotubules

모 Silt and clay

Sand

(1) Current so

(1) Sample

Fig. 3. - A. Stratigraphic column of the S-8 core. Textural distribution (\%), organic matter (\%) and $\mathrm{CaCO}_{3}(\%)$. A palaeoenvironmental interpretation is also shown for each chronostratigraphic unit. B. Index diversity of the foraminifera of the S-8 core. Shannon-Wiener, Margalef richness, Equitability and Fisher's alpha. A palaeoenvironmental interpretation is also shown for each chronostratigraphic unit. 
Table 3. - Number of individuals and species of benthic foraminifera in core S-4 (N, number of individuals).

\begin{tabular}{|c|c|c|c|c|c|c|c|c|c|c|c|c|c|c|c|c|c|c|c|}
\hline \multirow[t]{2}{*}{ Species $\backslash$ Samples } & \multirow{2}{*}{$\begin{array}{c}6 \\
\mathrm{~N}\end{array}$} & \multirow{2}{*}{$\begin{array}{c}7 \\
\mathrm{~N}\end{array}$} & \multirow{2}{*}{$\begin{array}{c}8 \\
\mathrm{~N}\end{array}$} & \multirow{2}{*}{$\begin{array}{c}9 \\
\mathrm{~N}\end{array}$} & \multirow{2}{*}{$\begin{array}{l}10 \\
\mathrm{~N}\end{array}$} & \multirow{2}{*}{$\begin{array}{l}11 \\
\mathrm{~N}\end{array}$} & \multicolumn{2}{|c|}{31} & \multicolumn{2}{|c|}{33} & \multicolumn{2}{|c|}{35} & \multicolumn{2}{|c|}{37} & \multicolumn{2}{|c|}{39} & \multicolumn{2}{|c|}{41} & \multirow[t]{2}{*}{ Total } \\
\hline & & & & & & & $\mathrm{N}$ & $\%$ & $\mathrm{~N}$ & $\%$ & $\mathrm{~N}$ & $\%$ & $\mathrm{~N}$ & $\%$ & $\mathrm{~N}$ & $\%$ & $\mathrm{~N}$ & $\%$ & \\
\hline \multicolumn{20}{|l|}{ Orden Rotaliida } \\
\hline Ammonia tepida & 1 & 2 & 5 & 6 & 52 & 2 & 264 & 85 & 261 & 86 & 210 & 68 & 259 & 86 & 281 & 93 & 218 & 71 & 1561 \\
\hline Cribroelphidium excavatum & & & & & & & 42 & 14 & 22 & 7 & 36 & 12 & 9 & 3 & 3 & 1 & 3 & 1 & 115 \\
\hline Haynesina depressula & & & & & & & & & & & & & & & & & 2 & 1 & 2 \\
\hline Haynesina germanica & & & & & & & 3 & 1 & 20 & 7 & 62 & 20 & 33 & 11 & 19 & 6 & 84 & 27 & 221 \\
\hline Orden Lituolida & & & & & & & & & & & & & & & & & & & \\
\hline Trochammina inflata & & & & & 2 & & & & & & & & & & & & & & 2 \\
\hline Total & 1 & 2 & 5 & 6 & 54 & 2 & 309 & 100 & 302 & 100 & 308 & 100 & 301 & 100 & 303 & 100 & 307 & 100 & 1900 \\
\hline $\mathrm{N}^{\circ}$ Species & 1 & 1 & 1 & 1 & 2 & 1 & 3 & & 3 & & 3 & & 3 & & 3 & & 3 & & 5 \\
\hline
\end{tabular}

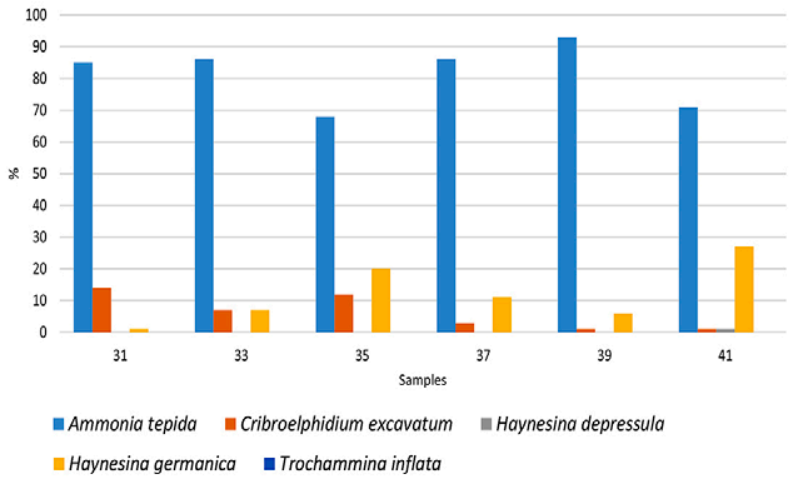

Fig. 4. - Benthic foraminiferal relative abundances from core S-8.

M9 it accounts for $30 \%$ of species, but its proportion falls to $7 \%$ in M10. Thus, the prevalence of Ammonia tepida falls progressively towards the coastline (M8), where other hyaline and porcellaneous species, with more halophiles and fewer euryhaline species, predominate. According to Murray (2006), the increase in salinity raises the likelihood of other less euryhaline species appearing in the assemblage. In the inlet, where the diversity of species is generally greater, Ammonia tepida decreases (by approximately 10\%-15\%) due to the proportional increase of the Miliolida order. Paraphysalidia paralica is the second most frequent species in the samples in the Almenara marsh, with 514 individuals and an overall proportion of $18 \%$. Its highest presence in the study area is recorded in M2 where it represents $95 \%$ of the total of individuals. In M1, it represents $17 \%$. Trichohyalus aguayoi is one of the few species present in all samples, with the exception of M10. It represents $7.7 \%$ of the total of the shells found and is the third most represented species. In $\mathrm{M} 8$, it reaches $41 \%$, in assemblages with Ammonia tepida. In contrast, in the inlet its presence is very low, and it is only recorded in M9. Haynesina germanica increases in more saline environments (Murray 2006). In the inner part of the marsh, it accounts for only $3 \%$ to $5 \%$ of the total of species, while its presence in the inlet rises to $7 \%$ in M9 and to $21 \%$ in M10. Along with Miliolinella eburnea, it is the species with the highest number of individuals in the inlet, and has similar ecological demands. In general, porcellaneous shell species appear more frequently in positions closer to the sea, although always in small numbers.

In M7 and M9, isolated increases of agglutinated species are observed (49 individuals in total). Only three species of agglutinated shell foraminifera were classified, the most abundant being Pseudothurammina limnetis (1.6\%), followed by Jadammina macrescens $(1 \%)$ and Trochammina inflata $(0.9 \%)$.

\section{Holocene sediments}

Seven sedimentary units were defined in core S-8, going from unit I at the base to unit VII at the top (Fig. $3 \mathrm{~A}$ ), based on sedimentological and palaeontological criteria (Fig. 3B, Table 3, Fig. 4). Unit I (samples 47-42), between -10 and $-8.3 \mathrm{~m}$, is composed of silty clay with quartz and carbonate sands. Mica, ferric concretions and plant remains are also abundant at this level. The biogenic component is scarce, especially at the base. Towards the top, brackish water ostracods [Cyprideis torosa (Jones, 1850)] are recorded, as well as bivalves and gastropods and some poorly preserved benthic foraminiferal tests [Ammonia tepida and Cribroelphidium excavatum (Terquem, 1875)]. The mean calcium carbonate content is high $(26 \%)$ throughout the unit, and the mean organic matter content is $3 \%$. Unit II, between -8.3 and $-6.9 \mathrm{~m}$ (samples 41-37), is similar to the previous one, although here the biogenic component is very abundant and well preserved: ostracod valves (Cyprideis torosa) and foraminifera [Ammonia tepida (83\%), Haynesina germanica (15\%) and Cribroelphidium excavatum (2\%)]. Regarding the indices calculated from the foraminifers identified, the average values of each parameter were as follows: Shannon-Wiener diversity 0.5, Margalef richness 0.4 , Equity 0.4 and Fisher's alpha 0.5 . The mean calcium carbonate content in this unit is $41 \%$ and the mean organic matter is $3 \%$; the organic matter percentage is higher at the base of this unit. Unit III, between 6.9 and $5.9 \mathrm{~m}$ (samples 35-31), is very rich in calcium carbonate, with sands and gravel of carbonate origin. The biogenic component is also covered by a carbonate film containing ostracods and foraminifera shells [Ammonia tepida ( $80 \%)$, Cribroelphidium excavatum $(11 \%)$ and Haynesina germanica (9\%)]. The average values of the indices calculated in the foraminifera studied are the following: 0.6 for the Shannon-Wiener diversity, 0.3 for Margalef richness, 0.5 for Equity and 0.5 for Fisher's alpha. Ferric concretions are abundant. The mean calcium carbonate content in this unit is $82 \%$ and the mean organic matter content is higher than $3 \%$.

Unit IV, between $-5.9 \mathrm{~m}$ and $-2.07 \mathrm{~m}$ (samples 30 17), is composed of silts and reddish clays with sands, in which quartz, mica, ferric concretions and carbonates predominate. From the biogenic point of view, it is ster- 


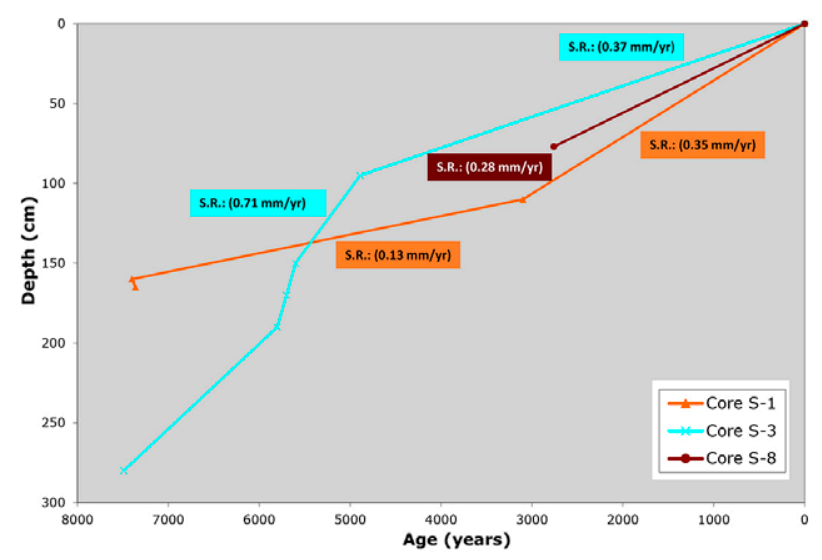

Fig. 5. - Age-depth model and sedimentation rates in $\mathrm{mm} / \mathrm{yr}$ from cores $\mathrm{S}-1, \mathrm{~S}-3$ and $\mathrm{S}-8$.

ile. The mean calcium carbonate content in this unit is $32 \%$ and the mean organic matter content is $4 \%$. Unit $\mathrm{V}$, between -2.07 and $-1.49 \mathrm{~m}$ (samples 16-12), is greyish brown in colour and consists of silts and clays with quartz, calcite and carbonate sand. There are abundant plant remains throughout the unit. The biogenic component is scarce (only some ostracods). The mean calcium carbonate content in this unit is $36.2 \%$ and the mean organic matter is above $3 \%$. Unit VI, between $-1.49 \mathrm{~m}$ and -0.65 $\mathrm{m}$ (samples 11-5) is formed by silts and brownish black clays with carbonate sands, very rich in fragments of peat that fill the shells of molluscs. There are rhizotubules at the top. From the biogenic point of view, charophytes, brackish water gastropods, bivalves and foraminifera (Ammonia tepida, Trochammina inflata) are recorded. Freshwater ostracods also appear [Darwinula stevensoni (Brady and Robertson, 1870) and Candona sp.]. In this unit, the mean calcium carbonate content is $39 \%$ and the mean organic matter is $7 \%$. Unit VII (the last $0.65 \mathrm{~m}$, samples 4-1) is similar to the previous one, although here the carbonate increases and the organic matter decreases. The biogenic component is low and decreases towards the top. The mean calcium carbonate content in this unit is $50 \%$ and the mean organic matter is $8 \%$.

Additionally, age-depth models have been included (Fig. 5) in order to estimate the sedimentation rates in three of the analysed cores (cores S-1, S-3 and S-8). The model is based on both the radiocarbon $\left({ }^{14} \mathrm{C}\right)$ and the amino acid racemization (AAR) ages (Table 1). Cores S-1 and S-8 exhibit similar estimated sedimentation rates $\left(0.24\right.$ and $0.28 \mathrm{~mm} \mathrm{yr}^{-1}$ respectively), whereas these sedimentation rates are somewhat higher in core S-3 $\left(0.37 \mathrm{~mm} \mathrm{yr}^{-1}\right.$ on average for the whole core and $\sim 0.71 \mathrm{~mm} \mathrm{yr}^{-1}$ for the interval between 7500 and 5000 cal yr BP). Nevertheless, as Figure 5 shows, the core $\mathrm{S}-8$ estimation is based on a single radiocarbon age, and AAR data are uncertain, so inferences about the sedimentation rate should be made with caution.

\section{DISCUSSION}

\section{Temporal development of the marsh}

The results suggest the existence of the following palaeoenvironments in the units defined in core S-8.
Unit I corresponds to the palustrine level because of the presence of frequent concretions of carbonates and plant remains and the scarcity of fossils (brackish water). The fauna content increases towards the top and is poorly conserved. Unit II indicates a brackish marsh palaeoenvironment; foraminifera are very frequent and are well conserved. The assemblage is formed by Ammonia tepida (83\%) Haynesina germanica (15\%) and Cribroelphidium excavatum (2\%); the last of these is more frequent towards the top, while Haynesina germanica is very abundant at the base of the unit. The sedimentary and palaeontological content described in unit II is also observed in unit III, which shows a percentage of calcium carbonate greater than $80 \%$. Unit III is interpreted as the desiccation of unit II. From the palaeoenvironmental point of view, unit IV is interpreted as an alluvial deposit invading the contemporary marsh. This reddish deposit has no bioclastic content: it is reddish clayey silt and it shows concentrated levels of quartz sand. Finally, units V, VI and VII indicate three stages of an oligohaline or freshwater marsh: a marsh environment at the base (unit V), a marsh with bodies of stable water (unit VI), and the recovery of the marsh environment at the top (unit VII). Ostracods (Darwinula stevensoni, Candona sp.), with articulated valves and good conservation, indicate freshwater/ oligohaline water. ${ }^{14} \mathrm{C}$ dating indicates an age between 2780 and 2740 cal yr BP for the stable oligohaline or freshwater marsh. Foraminifera are very scarce; the most frequent species is Ammonia tepida and, with the exception of sample 10, does not exceed 10 shells.

The correlation of five cores (S-1, S-2, S-3, S-8, and $\mathrm{S}-4)$ suggests that the characteristic palaeoenvironment during the early Holocene was a brackish water marsh (Fig. 6), recorded only in S-8 (units I and II), which later dried (unit III) in correlation with S-1, S-2 and S-3 (unit I). According to relative chronology, this marsh must be older than $8.2 \mathrm{ka}$, given that the overlying level is assigned to the $8.2 \mathrm{ka}$ event. Furthermore, according to the regional model of Holocene evolution (Xàbia and Pego marshes), the first marsh deposits date back to 9000 cal yr BP (Fumanal et al. 1993), and are on top of fluvial facies (peat), although they are interpreted as brackish lagoon by Brisset et al. (2018), who noted indicating phases of barrier-lagoon system development due to the stepwise inland migration of the coastline.

The drying episode recorded in three cores (unit I, cores S-1, S-2 and S-3) and through relative chronology is assigned to the middle Holocene ( $8.2 \mathrm{ka}$ event), a time when the area of study had an irregular morphology, covered by a massive precipitation of carbonates formed by the drying of this brackish marsh. In a marshy environment in depressed areas, the carbonate-rich groundwaters rose to the surface in spite of intermittent desiccation events (Wright and Platt 1995). This deposit predates 7570 cal yr BP (Table 1), constitutes the floodable substrate of the sea level rise corresponding to MIS 1, and could be related to the cold and dry 8.2 ka event or to the Younger Dryas episode. This age is confirmed by geoarchaeological information, since an epipalaeolithic site (Gran Estany) sits on this surface (Fig. 6), dating the carbonate level to before 


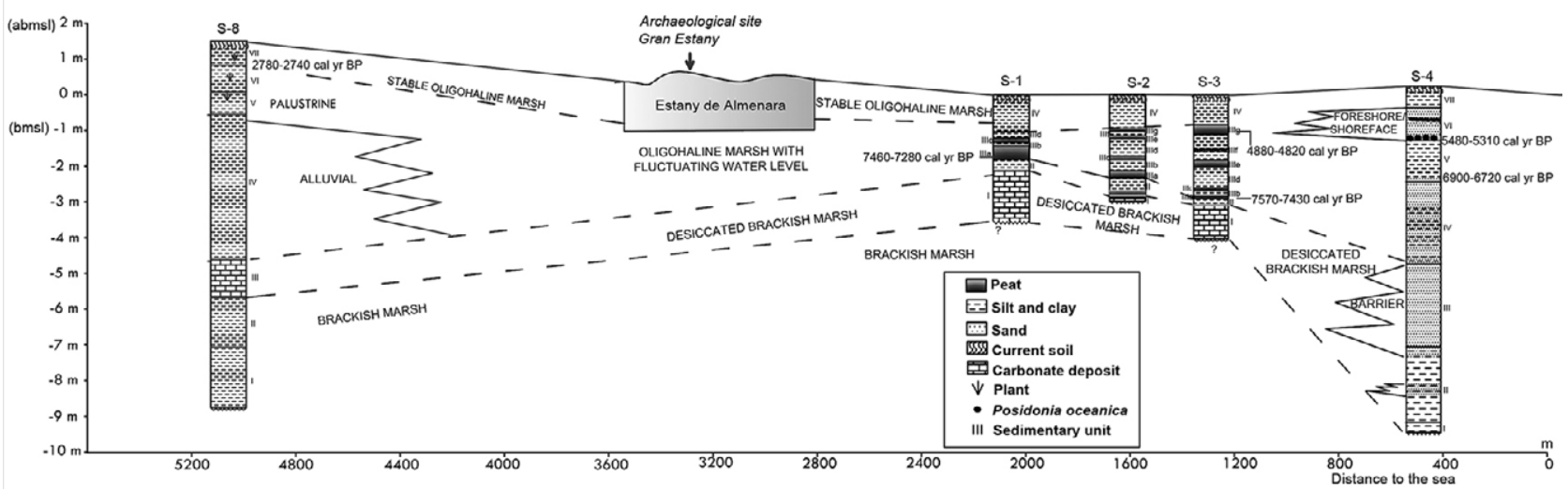

Fig. 6. - Correlation of cores S-1, S-2, S-3 and S-8 and proposed palaeoenvironmental interpretation.

7000 years BP (Gusi 1978). According to Gusi (1978), the pollen analysis in these studies shows that human occupation took place in a rich ecosystem consisting of a marsh environment surrounded by extensive vegetation, mainly comprising cork oaks covering the coastal mountains and the alluvial piedmont slope (Gusi 1978). Therefore, taking into account the regional model of the first marsh deposit date, the brackish marsh of the early Holocene (units I, II of S-8) and its desiccation seem to be more related to the $8.2 \mathrm{ka}$ event than to the Younger Dryas event. However, radiometric dating is lacking at this level, so these data should be interpreted with caution. Similar time sequences have been found in the Rhone delta at 9800-8200 cal yr BP (Amorosi et al. 2013) and in the Adriatic Sea at 9200-7700 cal yr BP (Amorosi et al. 2017).

The area of carbonate deposition is separated from the sea by a barrier whose backshore facies are recorded in unit III of core S-4, located near the coastline (Blázquez et al. 2017). From 7570 cal yr BP until 4820 cal yr BP $(3100 \pm 780$ yr BP AAR) in S-3 and until at least 2780 cal yr BP in S-8 (Table 1), an oligohaline or freshwater marsh (late Holocene) is recorded, indicating that a freshwater environment prevailed due to the considerable groundwater inputs, rainfall and riverine discharge into the marsh; therefore, the influence of the sea is limited. Facies of oligohaline or freshwater marsh are recognized, although oscillations are reflected in alternating dark, peat-rich sediments, and others showing lighter colours that are rich in biogenic remains and occasionally with rhizotubules and carbonate concretions. Near the coastline (S-4), these facies correspond to a marsh (unit IV) associated with brackish water and foraminifera (Ammonia tepida, Haynesina germanica, Cribroelphidium excavatum and Spirillina sp.). At this point, the maximum flood areas, in the foreshore fa-

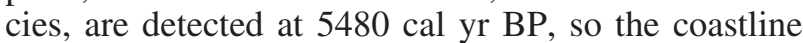
would have been located at least $450 \mathrm{~m}$ inland from its present-day position (Rodríguez-Pérez et al. 2018). In other areas of the Valencian gulf, the maximal inland position of the beach is dated at 7500-7200 cal yr BP (Carmona and Ruiz 2011, Brisset et al. 2018); therefore, the relative position of the sea in different areas of the Valencian gulf is highly conditioned by tectonic factors (Blázquez et al. 2017). The beach, which would have comprised pebbles (as it does today) would have been affected by the sedimentation of rhizomes of Posidonia oceanica (Delile, 1813), probably due to constant high-energy marine episodes. From approximately 4820 cal yr BP onwards, a more stable marsh with marine influence is recorded, as indicated by the biofacies found [Ammonia tepida and Cribroelphidium excavatum, mixed with marine foraminifera such as Rosalina globularis D'Orbigny, 1826, Ammonia beccarii (Linné, 1758) and Cibicidoides lobatulus (Walker and Jacob, 1798)]. The marsh dried out in recent times, immediately prior to the current soil formation process, with sediments rich in rhizotubules, lenticular carbonate and gypsum concretions.

\section{The present-day marsh and anthropogenic influence}

The predominant foraminiferal assemblage in the Almenara marsh today comprises three orders (Rotaliida, Lituolida and Miliolida) whose presence is determined by the position of the sample in the marsh and by the sediment. In the inner part of the marsh, with silt and clay rich in organic matter, the order Rotaliida predominates (Ammonia tepida, Paraphysalidia paralica, Trichohyalus aguayoi and Haynesina germanica), while nearer the sea the order Miliolida is the most frequent (Miliolinela eburnea), with silt and clay and sand. The order Lituolida is found both in the interior of marshes (Trochammina inflata) and in the inlet (Pseudothurammina limnetis). Therefore, two types of environment can be observed in the Estany de Almenara: on the one hand (M1-M8), a low-salinity marsh, at some distance from the coastline, rich in organic matter and affected by marine infiltrations; and on the other, a section directly influenced by the sea, located in the inlet (M9-M10) communicating the marsh with the sea; it is characterized by a higher presence of sand (quartz) and a lower percentage of organic matter.

With regard to the ecological index (Fig. 7), the samples from the interior are less diverse than those collected near the coast. The highest diversity indexes are obtained near the coast (M9-M10). The Shannon- 

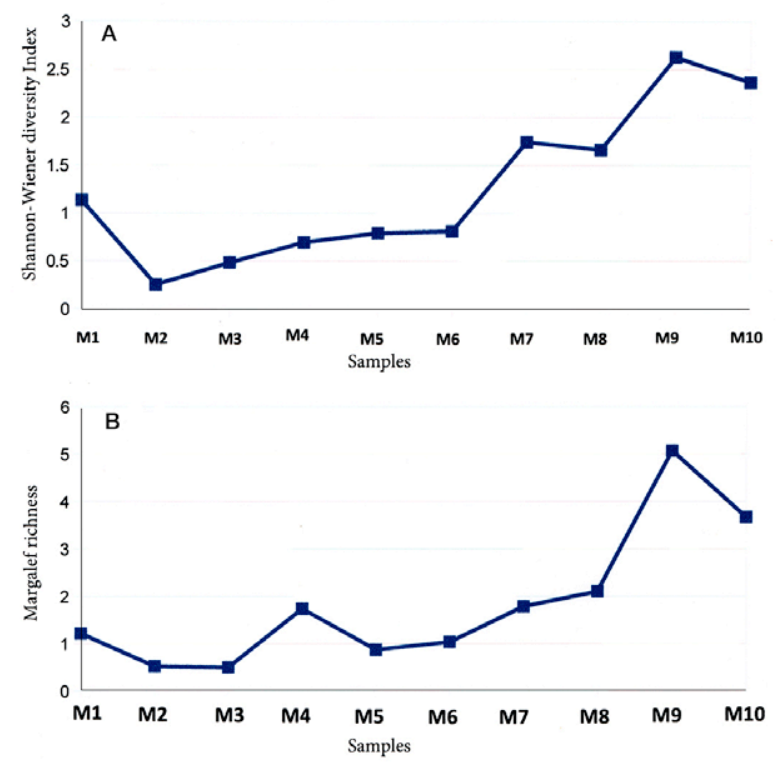

Fig. 7. - Diversity indices of surface sediment (present-day samples). A, Shannon-Wiener diversity index. B, Margalef richness.

Wiener index is low in the interior samples and above 2 in the inlet samples; the Margalef richness is above 3.5 in the inlet and barely exceeds 2 in samples from the interior of the marsh. The ecological indices of the channel indicate a marine environment (Murray 2006) similar to that of the estuaries and coastal lagoons that are steadily connected to the sea (Diz et al. 2004). The lower diversity in the marsh environment is attributed to the high instability of the environment and occasional reproductive explosions of a few species (Murray 1982 ).

The values of diversity in the thanatocoenosis (allochthonous tests) are higher in the samples studied than those in the biocenosis (autochthonous tests). This is attributable to the entrance by transport of allochthonous species as to the fact that the thanatocoenosis is formed by the accumulation in time of successive generations of living foraminifera (Murray 1982). As for the thanatocoenosis, the Shannon-Wiener diversity $(<1)$ is comparable to that of the Torreblanca marsh (Guillem 2007) or the Little Dipper Harbour Marsh, in Canadá (Patterson et al. 2004).

\section{The palaeoenvironmental evolution: regional and local factors}

Although the Almenara is now an artificial marsh, and the foraminiferal assemblage found may therefore not be representative of the foraminiferal assemblage that would have colonized the natural marsh during the early Holocene, the fossil assemblage of the basal level (unit I, II of core S-8) is quite similar. In both cases the dominant assemblage consists of Ammonia tepida and Haynesina germanica, although in the present-day marsh other species such as Paraphysalidia paralica and Trichohyalus aguayoi are also recorded. Trochammina inflata is also identified but it is not stained, and so it is not considered an autochthonous test. The assemblage studied in the recovered area (wetland) or
Estany de Almenara (Fig. 1D), (especially in samples M9 and M10, located nearest the coast) is similar to those found in present-day sediments of the estuaries and brackish lagoons. In the estuaries of the Odiel, Piedras and Gaudiana rivers, the most common calcareous species are Ammonia beccarii, Ammonia inflata (Seguenza, 1862) and Ammonia tepida, accompanied in this case by Cribroelphidium vadescens (Cushman and Brönnimann, 1948) and Astrononion stelligerum (D’Orbigny, 1839) (Ruiz et al. 2005). Ammonia beccarii is the dominant calcareous species in the brackish lagoon of Venice, with Haynesina paucilocula (Cushman, 1944) as secondary taxa (Serandrei Barbero et al. 1999). Furthermore, this assemblage is also found in Holocene sediments of estuaries and brackish lagoons in the Atlantic and Cantabrian coast (Leorri and Cearreta 2004, Alday et al. 2006). The Guadalquivir estuary also shows a similar brackish estuarine assemblage dominated by Ammonia tepida with Elphidium translucens Natland, 1938 and Elphidium granosum (D’Orbigny, 1846) (Rodríguez-Ramírez et al. 2015). In Holocene sequences of the western Mediterranean marshes Ammonia tepida, Cribroelphidium excavatum, Trichohyalus aguayoi, Haynesina germanica and Miliolinella eburnea are recorded (Blázquez and Usera 2010, Carmona et al. 2016).

The comparison between the foraminiferal assemblages of the present-day marsh and those recorded in the core sediment record indicates the similarity between the current facies and the marsh palaeoenvironment recorded in the early Holocene (prior to the $8.2 \mathrm{ka}$ event). The predominant species in both cases is Ammonia tepida. This species is stained and its shells are the most frequent in the present-day assemblage in the interior marshland (accounting for more than $65 \%$ in samples M1-M6, with the exception of M2) and for more than $70 \%$ in the Holocene assemblage (samples 41-31). Haynesina germanica is the other species found (also stained) although in the present-day samples it only appears near the sea, probably due to its greater salinity demand (Murray 2006). Ammonia tepi$d a$ and Haynesina germanica are common in marginal marine environments with highly variable organic matter content. These infaunal euryhaline species tolerate wide variations of salinity and thrive in hyposaline (brackish) coastal lagoons, estuaries, tidal marshes, etc. Temperature does not seem to be an important limiting factor since they are found in both warm and cold environments (Murray 2006). Additionally, Ammonia spp. are able to resist low oxygen levels and may even be facultative anaerobes (Pawlowski et al. 1995). In any case, this assemblage reflects higher salinity than in the oligohaline/freshwater environment identified between 7570 cal yr BP and at least 2780 cal yr BP (S1, S2 and S-3 cores; Fig. 4), which is characterized by the absence of foraminifera and by the dominance of freshwater/oligohaline species of gastropods and ostracods. The fluctuations in the water level and its oligohaline or freshwater character during the middle Holocene indicate that the modern-day (reclaimed) marsh shows more stable bodies under anthropogenic control for agricultural purposes and also more brackish bodies. 
The differences in the benthic foraminiferal assemblage may reflect changes in climate during the Holocene. The higher salinity of the marsh in the early Holocene and the present-day marsh may be due to a reduction of the braking action of the aquifer on the saltwater intrusion, probably due to climatic changes (lower rainfall and lower recharge) or anthropogenic activity (overexploitation of aquifers) in the case of the present-day marsh. The lower salinity of the water of the oligohaline marsh may be related to the greater contribution of the Les Valls aquifer, rainfall and surface runoff, which must have occurred above all between 7500-4300 yr BP (Fig. 4), since the pollen and sedimentary records of the Iberian Peninsula indicate a warm and humid phase (Dupré et al. 1988, Carrión et al. 2010). The fluctuations in the water level of the marsh have been associated with cyclic eustatic variations by several authors (Mediato 2016). Other studies have associated these fluctuations with generalized climatic phenomena (increased precipitation and humidity due to low pressure in the south of Europe) in the Northern Hemisphere (Blázquez et al. 2017), according to the model proposed by other authors for the Mediterranean for the last 7000 years (Zazo et al. 2008, Amorosi et al. 2017). Sabatier et al. (2012) also propose the increase in storm activity during Holocene cold events over the North Atlantic and Mediterranean regions, especially at 6300-6100, 5650-5400, 44004050 and $3650-3200$ cal yr BP, among others. The contemporary alluvial deposit identified in core S-8 (Fig. 4) indicates the importance of the hillside contributions entering the marsh. According to Figure 4, the alluvial fan (unit IV) is correlated with unit III of cores S1, S2, S3, whose age ranges from 7500 to 4800 cal yr BP. Similar alluvial sediments are recorded in nearby areas (Usera et al. 2006). This deposit shows localized levels of sand (Fig. 3A) with quartz, calcite and mica that indicate variations in the energy of the contribution and may be related to the different facies detected in unit III of cores S-1, S-2 and S-3, produced by changes in the water sheet (Fig. 4). Therefore, in this area, regional and local factors (contributions of the aquifer, rainfall and surface runoff, and tectonics) decisively affected the palaeoenvironmental evolution when the sea level was stable.

Finally, the sedimentary record found in the Almenara marsh is interpreted as a combination of natural filling and human activity favouring erosion in recent times. According to the historical records, the siltation was favoured by human activity such as land reclamation, which was especially effective during the nineteenth century (Rosselló 1993). The marsh was dried for growing rice and maize, and also for health reasons in order to prevent the infectious diseases associated with wet areas (Obiol 1994). According to Obiol (1994), the desiccation of the marsh and agricultural speculation were favoured by the government policy of granting lands and water resources to private firms, and this process of privatization led to the fragmentation of the land and its appropriation by large companies. Today, agricultural uses predominate in the wetland, but the Spanish Ministry of the Rural and Marine Envi- ronment has introduced measures to reclaim the central part of the marsh as an area of natural interest, now known as the Estany de Almenara. These measures should enable the area to remain inside the RAMSAR Convention and also to obtain other more powerful forms of official protection. If this is achieved, other new areas in the marsh might be recovered as well.

\section{CONCLUSIONS}

From the palaeoenvironmental point of view, units I, II and III of core S-8 represent different stages of a brackish marsh: unit I corresponds to a palustrine medium which reaches its maximum development in marsh facies (unit II) and undergoes desiccation (unit III). In contrast, units V, VI and VII indicate three stages of an oligohaline or freshwater marsh: a marsh environment at the base (unit V), a marsh with bodies of stable water (unit VI) and the recovery of the marsh environment at the top (unit VII).

The succession of palaeoenvironments indicates a brackish marsh during the early Holocene (similar to the present-day marsh) prior to the 8.2 ka event, which desiccated as a result of the cold and dry $8.2 \mathrm{ka}$ event. The foraminiferal assemblage recorded is much poorer than the current one, although it also reflects the brackish nature of the water. During the Middle and Late Holocene a freshwater or oligohaline marsh was formed with fluctuating levels occupying the entire area, coinciding with a powerful alluvial contribution recorded in core $\mathrm{S}-8$. According to data from cores $\mathrm{S} 1, \mathrm{~S}-3$ and $\mathrm{S}-8$, this oligohaline or freshwater marsh is recorded from 7570 cal yr BP and at least until 2780 cal yr BP. During the last stage, the marsh water level stopped fluctuating and remained stable until more recent times. This palaeoenvironmental phase may be related to a moment of greater entry of groundwater, rainfall and surface runoff to the marsh, probably in response to a climatic episode characterized by higher rainfall.

The present-day benthic foraminiferal assemblage in the Almenara marsh comprises Ammonia tepida, Paraphysalidia paralica, Trichohyalus aguayoi, Haynesina germanica and Trochammina inflata. This assemblage of species indicates a brackish marsh and is similar to the one detected during the early Holocene. The distribution of the species (and orders) depends on their position in the marsh: in the interior the Rotaliida order predominates, while in positions closer to the sea the Miliolida order is the most frequent. The diversity and richness of foraminifera increases progressively towards the coast.

The changes in sea level are responsible for the larger-scale spatial and temporal palaeoenvironmental variations linked with inland migration of the coastline during the Holocene. Nonetheless, over the last 7000 years the climate signal has been a decisive factor in controlling the fluctuation that characterizes the freshwater/oligohaline marsh, since the low salinity seems to indicate isolation from the open sea in both the north and south of the marsh. In this context, the behaviour of the aquifers and the contribution of freshwater of other kinds (surface runoff, rainfall) plays a key role. 
The increase in salinity of the present-day marsh may be related to the current climate change (increased drought), which reduces the contribution of the aquifers and, in turn, its braking effect on the salt wedge. As for anthropic activity, the overexploitation of the aquifers also favours the increase in salinity. In the short and medium term, the increase in salinity constitutes a danger for agricultural use in the area.

\section{ACKNOWLEDGEMENTS}

This publication was partially supported by Projects UCV/2011-006-013, UCV/2012-006-003, UCV/2016153-001, UCV/2017-153-001 and UCV/2018-153002. The authors thank Dr Francesc Mezquita for classifying the ostracods and Dr Jordi Guillem for his help with the age-depth model. We thank Michael Maudsley for helping with the English text.

\section{REFERENCES}

Alday M., Cearreta A., Cachão M., et al. 2006. Micropaleontological record of Holocene estuarine and marine stages in the Corgo do Porto rivulet (Mira River, SW Portugal). Estuar. Coast. Shelf Sci. 66: 532-543.

https://doi.org/10.1016/j.ecss.2005.10.010

Amorosi A., Rossi V., Vella C. 2013. Stepwise post-glacial transgression in the Rhône Delta area as revealed by high-resolution core data. Paleogeog. Paleoclimatol. Paleoecol. 374: 314-326. https://doi.org/10.1016/j.palaeo.2013.02.005

Amorosi A., Bruno L., Campo B., et al. 2017. Global sea-level control on local parasequence architecture from the Holocene record of the Po Plain, Italy. Mar. Pet. Geol. 87: 99-111. https://doi.org/10.1016/j.marpetgeo.2017.01.020

Anthony E.J., Marriner N., Morhange C. 2014. Human influence and the changing geomorphology of Mediterranean deltas and coasts over the last 6000 years: From progradation to destruction phase? Earth-Sci. Rev. 139: 336-361. https://doi.org/10.1016/j.earscirev.2014.10.003

Blázquez A.M., Usera J. 2010. Palaeoenvironments and Quaternary foraminifera in Elx coastal lagoon (Alicante, Spain). Quat. Int. 221: 68-90.

https://doi.org/10.1016/j.quaint.2009.06.033

Blázquez A.M., Rodríguez-Pérez A., Torres T., et al. 2017. Evidence for Holocene sea level and climate change from Almenara marsh (Western Mediterranean). Quat. Res. 88: 206-222. https://doi.org/10.1017/qua.2017.47

Brisset E., Burjachs F., Ballesteros B., et al. 2018. Socio-ecological adaptation to Early-Holocene sea-level rise in the western Mediterranean. Glob. Planet. Change 169: 156-167. https://doi.org/10.17632/x2mtvmbgft.1

Carmona P., Ruiz J.M. 2011. Historical morphogenesis of the Turia River coastal flood plain in the Mediterranean litoral of Spain. Catena 86: 139-149.

Carmona P., Ruiz J.M., Blázquez A.M., et al. 2016. Environmental evolution and Middle-Late Holocene climate events in the Valencia lagoon (Mediterranean coast of Spain). Holocene 26: 1750-1765. https://doi.org/10.1177/0959683616645940

Carrión J.S., Fernández S., González-Sampériz P., et al. 2010. Expected trends and surprises in the Lateglacial and Holocene vegetation history of the Iberian Peninsula and Balearic Islands. Rev. Palaeobot. Palynology. 162: 458-475. http://hdl.handle.net/2160/6778

Diz P., Francés G., Costas S., et al. 2004. Distribution of benthic foraminifera in coarse sediments, ría de Vigo, NW Iberian Margin. J. Foraminifer. Res. 34: 258-275. https://doi.org/10.2113/34.4.258

Dupré M. Fumanal M.P., Sanjaume E., et al. 1988. Quaternary evolution of Pego coastal lagoon (Southern Valencia, Spain). Paleogeog. Paleoclimatol. Paleoecol. 68: 291-299. https://doi.org/10.1016/0031-0182(88)90046-6

Fisher R.A., Corbett A.S., Williams C.B. 1943. The relation between the number of species and the number of individuals in a random sample of an animal population. J. Anim. Ecol. 12: $42-58$.

https://doi.org/10.2307/1411

Fontboté J.M., Guimerà J., Roca E., et al. 1990. The Cenozoic geodynamic evolution of the Valencia trough (Western Mediterranean). Rev. Soc. Geol. España. 3: 249-259.

Fullana Montoro J. 2001. Plan de protección de recursos hídricos de la zona húmeda de Almenara. Ministerio de Medio Ambiente. Castellón.

Fumanal M.P., Usera J., Viñals M.J., et al. 1993. Evolución cuaternaria de la Bahía de Xàbia (Alicante). In: Fumanal M.P., Bernabeu J. (eds), Estudios sobre Cuaternario, Universitat de València, pp. 17-26.

Guillem J. 2007. Tafonomía, taxonomía y ecología de los foraminíferos de la albufera de Torreblanca. Ph.D. thesis, Serv. Publ. Univ. València, València.

Gusi F. 1978. Ecosistemas y grupos culturales humanos en las comarcas de Castellón durante el Pleistoceno y mitad del Holoceno. Quad. Prehist. Arq. Castelló. 5: 189-206.

Hammer O., Harper D., Ryan P. 2006. Paleontological statistics, version 1.57 .

Hayward B.W., Cedhagen T., Kaminski M., et al. 2017. World Foraminifera Database. Accessed on 2017-03-24 at http://www.marinespecies.org/foraminifera

Jennings A.E., Nelson A.R. 1992. Foraminiferal assemblage zone in Oregon tidal marshes-relation to marsh floral zones and sea level. J. Foramin. Res. 22: 13-30. https://doi.org/10.2113/gsjfr.22.1.13

Leorri E., Cearreta A. 2004. Holocene environmental development of the Bilbao estuary, northern Spain: sequence stratigraphy and foraminiferal interpretation. Mar. Micropaleontol. 51: 75-94. https://doi.org/10.1016/j.marmicro.2003.08.003

Loeblich A.R., Tappan H. 1987. Foraminiferal genera and their classification. Van Nostrand Reinhold Company, New York, $970 \mathrm{pp}$.

Magurran A.E. 2001. Ecological diversity and its measurement. In: Moreno C.E. (ed.), Métodos para mediar la biodiversidad, vol. 1 .

Mediato J.F. 2016. Oscilaciones del nivel del mar desde el Pleistoceno superior en el sector costero Sagunto-Benicasim (Valencia-Castellón). Registro sedimentario, geoquímico e histórico. Ph.D. thesis. Universidad Complutense de Madrid, Madrid.

Murray J. 1982. Benthic foraminifera: The validity of living, dead or total assemblages for the interpretation of palaeoecology. J. Micropalaeont. 1: 137-140. https://doi.org/10.1144/jm.1.1.137

Murray J. 2006. Ecology and Applications of Benthic Foraminifera. Cambridge University Press. $426 \mathrm{pp}$ https://doi.org/10.1017/CBO9780511535529

Obiol E.M. 1994. Desecaciones, arroz y demografía en el s. XIX: El caso de "Els Estanys" de Almenara. Cuadernos de Geografía 55: $109-121$

Patterson R.T., Gehrels W.R., Belknap D.F., et al. 2004. The distribution of salt marsh foraminifera at Little Dipper Harbour New Brunswick, Canada: implications for development of widely applicable transfer functions in sea-level research. Quat. Int. 120: $185-194$. https://doi.org/10.1016/j.quaint.2004.01.017

Pawlowski J., Bolivar I., Farhni J., et al. 1995. DNA analysis of Ammonia beccarii morphotypes: one or more species? Mar. Micropaleontol. 26: 171-178 https://doi.org/10.1016/0377-8398(95)00022-4

Pérez Cueva A. 1979. El cuaternario continental de la Plana de Castelló. Cuadernos de Geografía 24: 39-54.

Pirazzoli P. 2005. A review of possible eustatic, isostatic and tectonic contributions in eight late-Holocene relative sea-level histories from the Mediterranean area. Quat. Sci. Rev. 24: 1989-2001. https://doi.org/10.1016/j.quascirev.2004.06.026

Rodríguez-Pérez A., Blázquez A.M., Guillem J., et al. 2018. Maximum flood area during MIS 1 in the Almenara marshland (western Mediterranean): Benthic foraminifera and sedimentary record. Holocene. 28: 1452-1466. https://doi.org/10.1177/0959683618777069

Rodríguez-Ramírez A., Pérez-Asensio J.N, Jiménez-Moreno G., et al. 2015. Atlantic extreme wave events during the last four millennia in the Guadalquivir estuary, SW Spain. Quat. Res. 83: $24-40$. https://doi.org/10.1016/j.yqres.2014.08.005

Rosselló V.M. 1993. Albuferas mediterráneas. Cuadernos de Geo- 
grafía 53: 35-64.

Ruiz F., González-Regalado M.L., Pendón J.G., et al. 2005. Correlation between foraminifera and sedimentary environments in recent estuaries of Southwestern Spain: Applications to Holocene reconstructions. Quat. Int. 140-141: 21-36. https://doi.org/10.1016/j.quaint.2005.05.002

Sabatier P., Dezileau L., Colin Ch., et al. 2012. 7000 years of paleostorm activity in the NW Mediterranean Sea in response to Holocene climate events. Quat. Res. 77: 1-11. https://doi.org/10.1016/j.yqres.2011.09.002

Sanjuán D., Blázquez A.M. 2017. Foraminíferos bentónicos actuales en la marjal de Almenara (Castelló): subzonación de ambientes parálicos mediante la taxonomía y la ecología. Nereis: Rev. Iberoam. Interdiscip. Mét. Model. Simul. 9: 103-114.

Serandrei-Barbero R., Carbognin L., Taroni G., et al. 1999. Distribution of recent benthic foraminifera in the southern basin of the Venice lagoon (Italy): Statistical evaluation of taxa significance. Micropaleontology. 45: 99-111.

https://doi.org/10.2307/1486205
Shannon C.E., Wiener W. 1949. The matematical theory of communication. University of Illinois Press, Urbana.

Usera J., Blázquez A.M., Guillem J., et al. 2006. Evolución holocena de la Marjal de Peñíscola (Castellón, España) deducida del estudio de sus foraminíferos fósiles. Rev. Esp. Micropaleontol. 38: 381-393.

Walton W.R. 1952. Techniques for recognition of living foraminifera. Contrib. Cushman Found. Foramin. Res. 3: 56-60.

Wright V.P., Platt N.H. 1995. Seasonal wetlands carbonate sequences and dynamic catenas: a reappraisal of palustrine limestones. Sediment. Geol. 86: 203-210. https://doi.org/10.1016/0037-0738(95)00080-R

Zazo C., Dabrio C.J., Goy J.L., et al. 2008. The coastal archives of the last $15 \mathrm{ka}$ in the Atlantic-Mediterranean Spanish linkage area: sea level and climate changes. Quat. Int. 181: 72-87. https://doi.org/10.1016/j.quaint.2007.05.021 